\title{
Stretching the Margins: The Geographic Nexus in Environmental Law
}

\author{
Daniel A. Farber*
}

In environmental law, a recurring issue involves the geographic nexus-the connection required to give an individual or government a legitimate interest in an environmental problem in a given locale. The nexus issue arises in a broad range of contexts, from standing decisions such as Defenders and $\mathrm{Na}-$ tional Wildlife Federation, to Dormant Commerce Clause decisions and their relatives in GATT and ECJ jurisprudence. In Part I, the author explores the use of the geographic nexus to define when individuals have suffered cognizable environmental injuries. He then explores, in Part II, what type of nexus a government must show as a basis for environmental regulation. He argues in Part III that we need a pragmatic, flexible approach to the geographical nexus. Globalism and localism, the two leading perspectives on the geographic nexus, are both too inflexible. Localism places talismanic weight on physical location while globalism attempts to erase geography. Each perspective is insufficiently attentive to the values represented by the other. We must expect the geographic nexus to evolve along with changing concepts of sovereignty and developing perceptions of environmental issues. In applying such an evolutionary approach, tribunals should be receptive to signals from the international community, or in the United States, from Congress, regarding the legitimacy of transboundary regulatory interests.

\section{INTRODUCTION}

What kind of connection with an environmental problem is necessary to form a basis for legitimate action? Consider the following:

An American nature lover files suit to save elephants and leopards in Sri Lanka. ${ }^{1}$

The United States bans imports of Mexican tuna to protect dolphins on the high seas. ${ }^{2}$

$\because$ Acting Associate Vice President for Academic Affairs, Associate Dean for Faculty and Henry J. Fletcher Professor of Law, University of Minnesota. I would like to thank Jim Chen and Bob Hudec for their helpful comments.

1. See Lujan v. Defenders of Wildlife, 504 U.S. 555, 563-64 (1992) (reviewing challenge to standing under the Endangered Species Act).

2. See United States: Restrictions on Imports of Tuna, GATT Doc. DS21/R (1992), compiled in GATT: Basic Instruments and Selected Documents 155 (39th Supp. 1993) [hereinafter TunaDolphin I (concluding various provisions of the Marine Mammal Protection Act violate GATT rules). 
The Dutch government prosecutes a local grocer for selling wild grouse killed in Britain. ${ }^{3}$

Are these the actions of overzealous meddlers or of vigilant environmental guardians?

Each of these situations resulted in a definitive legal ruling. All three tribunals-the United States Supreme Court, a GATT dispute resolution panel, and the European Court of Justice-concluded that the geographic nexus ${ }^{4}$ was insufficient. But this apparent consensus conceals a great deal of ambiguity and conflict within and among legal systems.

This article investigates the common thread running through each case: the conflict between localist and global perspectives in environmental law. ${ }^{5}$ For the localist, the physical location of an environmental harm is crucial in determining individual standing or governmental regulatory authority. ${ }^{6}$ The globalist, in contrast, sees the planetary ecology as a seamless web that renders location almost irrelevant. ${ }^{7}$ Both perspectives have their appeal, though neither is ultimately persuasive.

Part I of this article considers the geographical nexus at the individual level: What kind of geographic connection with an area does an individual need to mount a cognizable claim of environmental harm? This issue arises in the law of standing and when assessing damages for injury to natural resources. In both, a key issue is whether physical contact is a prerequisite for individual environmental claims.

Part II asks what kind of connection a government needs as the basis for environmental intervention. GATT panels, as well as American and European courts, have faced this problem. These tribunals must confront the conflict between globalism and localism in order to determine whether a government's desire to prevent extraterritorial harm counts as a legitimate justification for impeding free trade.

After appraising localism and globalism, Part III rejects both in favor of an evolutionary approach to the geographic nexus. Under this approach, physical location is not necessarily decisive. Instead, the tribunal must consider an environmental claim against the evolving backdrop of environmental law, using its own precedents and the decisions of other lawmaking authorities to assess the adequacy of the geographic nexus. Rather than focusing on physical presence, the evolutionary approach considers a broader range of connections with a lo-

3. See Case C-169/89, Criminal Proceedings Against Gourmetterie Van den Burg, 1990 E.C.R. I2143, 1-2161.

4. In this article, geographic nexus simply means the connection between an individual or government and an affected environmental location.

5. Christopher Stone aptly refers to this tension as the conflict between the perspective of the diplomat and that of the astronaut. See Christopher D. Stone, The Gnat is Older than Man: Global Environment and Human Agenda 33-34 (1993).

6. See id. at 34-37 (identifying a "local-regarding" matrix derived from five variations of harm threatening activity and the site of the concentrated harm).

7. See, e.g., Barry Commoner, The Closing Circle: Nature, Man, and Technology 33-38 (1971) (positing as "the first law of ecology [that] everything is connected to everything else"). 
cale. ${ }^{8}$ Like all compromises, this approach can do only imperfect justice to the conflicting values involved. Even so, it is superior to the alternatives, each of which is blind to the other side's opposing values.

\section{Physical Presence and Individual Injury}

\section{A. Standing}

To challenge a government action in court, a plaintiff must have standing to sue. As we will see, evidence of an injury to the plaintiff is critical to standing. Consequently, standing law provides an opportunity to examine conflicting judicial conceptions of injury. For the localist, physical presence is crucial: Only the person who sees the redwood can properly protest its logging. A globalist might allow a much more attenuated geographical nexus, or perhaps require none at all.

The leading United States decision on environmental standing, Sierra Club v. Morton, ${ }^{9}$ adopted a clearly localist approach. In seeking to challenge a development project in the Mineral King Valley of the Sequoia National Forest, the Sierra Club deliberately framed its complaint in globalist terms. It undoubtedly could have alleged that some of its members had physical contact with the area. Instead, it chose to base its claim of standing on its status as an organization with " 'a special interest in the conservation and the sound maintenance of the national parks, game refuges and forests of the country[.]" "10 The Supreme Court firmly rejected the view that "a mere 'interest in a problem" " is enough to confer standing. " The Court did make it clear, however, that noneconomic harm to the organization's members-including harm to aesthetic, conservation, or recreational values-may provide a sufficient basis for standing. ${ }^{12}$ As a result, Sierra Club established physical proximity to an affected area as the key to standing for environmental claims.

The dissenters argued for more liberal approaches to standing. Justice Douglas proposed that the Mineral King Valley, itself, should be allowed to serve as the nominal plaintiff. ${ }^{13}$ Despite this innovative suggestion, Justice Douglas, like the majority, primarily wished to ensure that "the voice of the existing beneficiaries of these environmental wonders . . be heard."14 Under his proposal, "those people who have so frequented the place as to know its values and wonders [would] be able to speak for the entire ecological commu-

8. In a sense, this inquiry is the mirror image of the traditional test for personal jurisdiction, which asks if a geographic area has the required minimum contacts to exercise jurisdiction over an outsider. The evolutionary approach asks whether the minimum contacts exist for the outsider to intervene in that geographical area's environment.

9. 405 U.S. 727 (1972).

10. Id. at 730 .

11. Id. at 739 .

12. Id. at 734 \& $\mathrm{n.7}$.

13. Id. at 741-42 (Douglas, J., dissenting) ("Contemporary public concern for protecting nature's ecological equilibrium should lead to the conferral of standing upon environmental objects to sue for their own preservation.").

14. Id. at 750 . 
nity." 15 On the other hand, "[t]hose who merely are caught up in environmental news or propaganda and flock to defend these waters or areas may be treated differently."16 Thus, despite his effort to recast standing law and his environmental sympathies, Justice Douglas did not completely break free from localism.

Justice Blackmun took a more globalist approach in his dissent. ${ }^{17} \mathrm{He}$ argued for an "imaginative expansion of our traditional concepts of standing in order to enable an organization [with] pertinent, bona fide, and well recognized attributes and purposes in the area of environment," to have standing to litigate environmental issues. ${ }^{18}$ Leaving no doubt about his rejection of localism, he closed with the "particularly pertinent observation and warning of John Donne": 19

No man is an Iland, intire of itselfe; every man is a peece of the Continent, a part of the maine; if a Clod bee washed away by the Sea, Europe is the lesse, as well as if a Promontorie were, as well as if a Mannor of thy friends or of thine owne were; any man's death diminishes me, because I am involved in Mankinde; And therefore never send to know for whom the bell tolls; it tolls for thee. ${ }^{20}$

Although the Court eschewed Justice Blackmun's globalism, it initially applied Sierra Club with a clear recognition of the difficulty of localizing environmental harms. In United States v. Students Challenging Regulatory Agency Procedures (SCRAP), ${ }^{21}$ the Court demonstrated a willingness to find individualized injury despite an attenuated chain of causation.22 The plaintiffs sought to challenge a rate order by the Interstate Commerce Commission that aggravated an existing price disparity between recycled and virgin materials. ${ }^{23}$ The plaintiffs were not shippers or buyers of recycled materials, but members of an environmental group. ${ }^{24}$ They claimed standing on the theory that the rate disparity discouraged recycling and therefore led to more pollution and greater use of natural resources, which purportedly affected the plaintiffs' local environment. ${ }^{25}$ Localism, stretched to this extent, becomes almost indistinguishable in practice from globalism. Although, under traditional localism, the plaintiff has standing only to protect her local environment, a sufficiently generous view of causation allows conduct in one location to form a link with environmental damage almost anywhere else, thereby virtually globalizing standing.

15. Id. at 752 .

16. $I d$.

17. See id. at 755 (Blackmun, J., dissenting). In his dissent Justice Brennan supported Justice Blackmun's conceptualization of standing. Id.

18. Id. at 757 (Blackmun, J., dissenting).

19. Id. at 760 .

20. Id. at 760 n.2 (quoting John Donne, Devotions: Upon Emergent Occasions 98 (John Sparrow ed., 1923) (1624)). (1973).

21. United States v. Students Challenging Regulatory Agency Procedures (SCRAP), 412 U.S. 669

22. Id. at $683-90$.

23. Id. at 676.

24. Id. at 675 .

25. Id. at 676,678 . 
In two recent opinions by Justice Scalia, however, the Court demonstrated that it now takes its localism seriously. The first and less sweeping of the opinions is Lujan v. National Wildlife Federation. ${ }^{26}$ As in Sierra Club, environmental groups challenged decisions regarding the use of public lands. Specifically, the environmental group challenged the legality of Bureau of Land Management decisions to lease public lands for activities such as mining. But unlike the Sierra Club, the National Wildlife Federation did not aim its challenge at any single parcel of land. Instead, it claimed that the government had used illegal procedures to permit future development in numerous locations. ${ }^{27}$ It based its standing to mount this broadly drawn challenge on evidence that its members used some specific tracts. ${ }^{28}$ Specifically, it alleged that several members engaged in activities "in the vicinity" covered by two of the 1250 challenged decisions. ${ }^{29}$

Justice Scalia rejected these standing allegations on two grounds. First, he addressed the standing claims based on the activities of group members in the vicinity of land covered by two of the challenged decisions. ${ }^{30}$ He held these claims of injury were insufficient due to the plaintiffs' failure to allege use of the specific tracts in question. ${ }^{31}$ The requirements of standing, Justice Scalia concluded, are "assuredly not satisfied by averments which state only that one of respondent's members uses unspecified portions of an immense tract of territory, on some portions of which mining activity has occurred or probably will occur ...."32 Second, even if the plaintiffs established standing with respect to a particular tract, such standing would not support a challenge to the entire body of decisions. ${ }^{33}$ Instead, the Court relegated the plaintiffs to a "case-bycase approach" 34 requiring that they establish standing for each separate tract of land. This approach would presumably only allow someone who used a particular tract to challenge the application of the policy to that tract. Thus, National Wildlife Federation is a monument to the jurisprudence of physical presence. It is little wonder that the Court went out of its way to disavow SCRAP, where the Court had expanded the localist Sierra Club test to the point of embracing globalist results. ${ }^{35}$

Justice Scalia continued his campaign for localism in Lujan v. Defenders of Wildlife. ${ }^{36}$ The Court never reached the ultimate issue in Defenders, whether the Endangered Species Act ${ }^{37}$ applies only to actions occurring in the United
26. 497 U.S. 871 (1990).
27. Id. at $885-88$.
28. Id. at $879-88$.
29. Id. at $880-81$.
30. Id. at 889 .
31. See id.
32. Id.
33. See id. at $892-93$.
34. Id. at 894 .
35. Id. at 889 (referring to $S C R A P$ as an "expansive expression" of standing under its facts which "has never since been emulated by this Court").
36. 504 U.S. 555 (1992).

37. 16 U.S.C. $\$ \$ 1531-1544$ (1994). 
States. ${ }^{38}$ The plaintiffs were again environmental groups, who claimed they would suffer harm due to federally supported projects in foreign countries, including Egypt and Sri Lanka. ${ }^{39}$ The Court held that the organizations lacked standing to file suit. ${ }^{40}$ In the process, the Court struck down the citizen suit provision of the Endangered Species Act. ${ }^{41}$

In Defenders, the plaintiffs alleged several forms of injury in an attempt to establish standing. Two members of the organizations alleged that they had visited, and hoped again to visit, the areas of Egypt and Sri Lanka that the projects would impact. ${ }^{42}$ Justice Scalia responded that standing could not be based on "[s]uch 'some day' intentions - without any description of concrete plans, or indeed even any specification of when the some day will be . . ."43 Justice Scalia was no more impressed by what he described disdainfully as the plaintiffs' more "novel standing theories." 44 Under the first of these theories, the "ecosystem nexus," "any person who uses any part of a "contiguous ecosystem' adversely affected by a funded activity has standing even if the activity is located a great distance away."45 Essentially, this claim was an attempt to revive Justice Douglas' rejected theory of standing in a different guise, for it would have allowed anyone who used an ecosystem to defend the ecosystem as a whole. The only difference is that individuals would bring suit in their own names rather than in the name of the ecosystem itself. Justice Scalia quickly brushed this theory aside as inconsistent with National Wildlife Federation. ${ }^{46}$ Although the Endangered Species Act aims, in part, to protect ecosystems, Justice Scalia found no basis for concluding that it created a cause of action on behalf of people who use parts of the ecosystem "not perceptibly affected" by the government's action. ${ }^{47}$

Justice Scalia found the plaintiffs' other two theories equally unimpressive. One, which they called the "animal nexus," would have given anyone who observes an endangered species in one location standing to protect the species in other locations. ${ }^{48}$ The other theory, the "vocational nexus," would have granted standing to anyone with a professional interest in the animal. ${ }^{49}$ To say that Justice Scalia was unpersuaded is an understatement. He seemed somewhat scandalized that anyone would propose such theories:

Under these theories, anyone who goes to see Asian elephants in the Bronx Zoo, and anyone who is a keeper of Asian elephants in the Bronx Zoo, has standing to sue because the Director of the Agency for International Development (AID) did not consult with the Secretary [of the Interior] regarding the

38. Defenders, 504 U.S. at 557-58.

39. Id. at 563 .

40. Id. at 578 .

41. Id. at 571-78.

42. Id. at $563-64$.

43. Id. at 564 .

44. Id. at 565 .

45. Id.

46. Id. at 565-66.

47. Id. at 566 .

48. Id.

49. Id. 
AID-funded project in Sri Lanka. . . . It goes beyond the limit, however, and into pure speculation and fantasy, to say that anyone who observes or works with an endangered species, anywhere in the world, is appreciably harmed by a single project affecting some portion of that species with which he has no more specific connection. ${ }^{50}$

Several other Justices, however, viewed the plaintiffs' nexus theories and their factual allegations more favorably. Joined somewhat surprisingly by Justice O'Connor, ${ }^{51}$ Justice Blackmun dissented once again, advocating broad environmental standing. ${ }^{52}$ Justice Stevens, while concurring in the judgment, believed that congressional findings about the importance of saving endangered species supplied adequate support for the plaintiffs' claims: "Given that finding, we have no license to demean the importance of the interest that particular individuals may have in observing any species or its habitat, whether those individuals are motivated by esthetic enjoyment, an interest in professional research, or an economic interest in preservation of the species."53 Justice Stevens also suggested that the "interest that confers standing in a case of this kind is comparable, though by no means equivalent, to the interest in a relationship among family members that can be immediately harmed by the death of an absent member, regardless of when, if ever, a family reunion is planned to occur." 54

A concurrence by Justice Kennedy, joined by Justice Souter, attempted to stake out a middle ground. 55 The Kennedy concurrence deserves careful attention, if only because he and Justice Souter were the swing voters on the law of standing.

Justice Kennedy entered two caveats to the Scalia opinion. First, although he agreed that the record was inadequate to support the plaintiffs' nexus theories, he was not willing, as a matter of law, to foreclose the ability of these theories to establish standing in future cases. ${ }^{56}$ Second, he saw an important role for Congress in defining the perimeter of injury in fact:

As Government programs and policies become more complex and far reaching, we must be sensitive to the articulation of new rights of action that do not have clear analogs in our common-law tradition. ... . In my view, Congress has the power to define injuries and articulate chains of causation that will give rise to a case or controversy where none existed before .... In exercising this power, however, Congress must at the very least identify the injury it seeks to vindicate and relate the injury to the class of persons entitled to bring suit. The

50. Id. at 566-67.

51. Eight years earlier, Justice O'Connor wrote a major opinion restricting standing. See Allen v. Wright, 468 U.S. 737 (1984) (holding parents of black children attending schools in states undergoing desegregation lacked standing to challenge tax exemptions for segregated private schools).

52. See Defenders, 504 U.S. at 589 (Blackmun, J., dissenting).

53. Id. at 582 (Stevens, J., concurring in the judgment).

54. Id. at 584 n.2. Justice Scalia "decline[d] to join Justice Stevens in this Linnaean leap." Id. at 567 n.3. (opinion of the Court).

55. See id. at 579 (Kennedy, J., concurring in part and in the judgement).

56. Id. 
citizen-suit provision of the Endangered Species Act does not meet these minimal requirements ....57

Both National Wildlife Federation and Defenders are obviously important to scholars of standing law. .88 For present purposes, however, they are most significant for their views of the geographic nexus required for individuals to have legitimate interests in environmental preservation. As we have seen, the Justices have taken three different positions in defining the required geographic nexus. Justice Scalia has twice championed the localist view, under which only direct physical contact with a specific locale can create a recognized individual interest. In contrast, Justice Blackmun has consistently argued for a more globalist approach, under which any demonstrated interest in an environmental problem is seemingly enough. Justice Kennedy has tended to side with Justice Scalia, but is less categorical in his insistence on physical presence. What is more intriguing, is that he, along with Justice Stevens, has also seen room for continued evolution in the definition of the geographic nexus, and envisions a role for Congress in this dynamic process.

\section{B. Contingent Valuation}

Standing law is part of the high theology of constitutional law. It seemingly has little in common with contingent valuation, a technique used to measure damages to natural resources. 59 Nevertheless, the two topics share a connection. In both, a critical issue is what kinds of individual interests in the environment should be considered tangible enough for recognition.

Economists measure the value of a resource by determining how much people would be willing to pay to preserve it. ${ }^{60}$ Current users would presumably be willing to pay for continued access to the resource. But other individuals might also be willing to pay something in order to preserve a resource. ${ }^{61}$ These nonuse values can take two forms. First, individuals who do not currently use a resource may be willing to pay to maintain an option for its future use. ${ }^{62}$ This "option value" is not in principle different from the options sold in futures markets that convey rights to purchase a good at a later date. Second, even individuals who never plan to use a resource may express a willingness to pay to preserve it due to intangible reasons, including a belief in the intrinsic value of the resources. ${ }^{63}$ Although these individuals lack a current or even a future

57. Id. at 580 .

58. See, e.g., Cass R. Sunstein, What's Standing After Lujan? Of Citizen Suits, "Injuries," and Article III, 91 Mich. L. Rev. 163 (1992); Harold J. Krent \& Ethan G. Shenkman, Correspondence, Of Citizen Suits and Citizen Sunstein, 91 Mrch. L. Rev. 1793 (1993).

59. For a discussion of contingent valuation, see David W. PEARCE \& R. KERRY TURNer, EcoNOMICS OF NATURAL RESOURCES AND THE ENVIRONMENT 148-53 (1990).

60. Or alternatively, economists may measure the value of a resource by determining how much individuals would demand in exchange for their permission to destroy it. The difference is not significant for the purpose of this article.

61. There is extensive literature on this topic. See, e.g., PEARCE \& TURNER, supra note 59, at 129137 (describing both option and existence values as part of the total economic value).

62. Id. at $130-34$.

63. Id. at $130-32,134-37$. 
connection with the resource, their willingness to pay for its preservation makes them part of the demand curve for its continued existence. These individuals are said to place an "existence value" on the resource. ${ }^{64}$

Although the context is different, these economic concepts should not strike legal readers as entirely unfamiliar, because they mirror distinctions in the law of standing. Sierra Club recognizes that all forms of current use value may provide a sufficient basis for standing. ${ }^{65}$ In Defenders, one plaintiff's standing claim rested on option value, since that plaintiff claimed a future intention to visit the areas in question. However, the Court rejected this as a basis for standing absent a showing of imminent travel plans. Or to put it another way, the Court required plaintiffs to show a firm plan to exercise their options and convert them to use values. ${ }^{66}$ In addition, the plaintiffs in Defenders based their standing on their professional interests in endangered species. ${ }^{67}$ This form of injury verged closer to existence value since it did not depend on direct use of the resource even in the future, but was insufficient to establish standing. Thus, in economic terms, the present law of standing is that only use value counts as legitimate.

Economists do not necessarily face the same legitimacy issue, since economics normally takes individual preferences as given rather than trying to assess them against some normative scale. ${ }^{68}$ The economist's problem, then, is primarily methodological rather than normative. Since neither option nor existence rights for natural resources trade on the market, they are not easy to price. Consequently, economists heatedly dispute whether these values can be meaningfully assigned "shadow prices." 69

This seemingly esoteric technical dispute has legal significance because courts must sometimes assess damages for harm to natural resources. Two federal statutes require government agencies to establish rules for assessing natural resources damages in such cases. Under the federal Superfund law, for example, site owners, waste generators, and transporters are responsible for injury to natural resources due to the release of hazardous wastes. ${ }^{70}$ Although private parties lack authority to collect these damages, defendants are liable to whatever government agency regulates the resource, and the agency may use

64. See id.

65. See text accompanying note 12 supra.

66. See text accompanying notes $42 \& 43$ supra.

67. See text accompanying note 49 supra.

68. See Howard F. Chang, An Economic Analysis of Trade Measures to Protect the Global Environment, 83 GEO. L.J. 2131, 2169-70 (1995) (defending the inclusion of nonuse valuation in economic theory).

69. See, e.g., Richard H. Pildes \& Cass R. Sunstein, Reinventing the Regulatory State, 62 U. CHr. L. REv. 1, 66-72 (1995) (expressing the need to consider unquantifiable factors such as "cultural consequences" when attempting to attach value to particular concerns); Note, "Ask a Silly Question ...": Contingent Valuation of Natural Resource Damages, 105 HARV. L. REv. 1981 (1992) (arguing that the contingent valuation method of measuring nonuse values is so speculative that results are meaningless).

70. Comprehensive Environmental Response, Compensation, and Liability Act of 1980 (CERCLA), Pub. L. No 96-510, 94 Stat. 2767 (1980) (codified as amended in scattered sections of 42 U.S.C.). In 1986, Congress amended Superfund, the popular name for CERCLA, in the Superfund Amendments and Reauthorization Act, Pub. L. No. 99-499, 100 Stat. 1613 (1986) (codified as amended in scattered sections of 42 U.S.C.). 
these damages only for restoration or replacement purposes only. ${ }^{71}$ Another federal statute, the 1990 Oil Pollution Act, creates similar liability to state or federal trustees for damages from oil spills. ${ }^{72}$ Under both statutes, a major question is whether contingent valuation can play a role in assessing damages.

The D.C. Circuit upheld the use of contingent valuation in Superfund cases in Ohio v. United States Department of the Interior. ${ }^{73}$ The court began by describing the methodology in question:

The CV [contingent valuation] process "includes all techniques that set up hypothetical markets to elicit an individual's economic valuation of a natural resource." CV involves a series of interviews with individuals for the purpose of ascertaining the values they respectively attach to particular changes in particular resources. Among the several formats available to an interviewer in developing the hypothetical scenario embodied in a CV survey are direct questioning, by which the interviewer learns how much the interviewee is willing to pay for the resource; bidding formats, for example, the interviewee is asked whether he or she would pay a given amount for a resource and, depending upon the response, the bid is set higher or lower until a final price is derived; and a "take or leave it" format, in which the interviewee decides whether or not he or she is willing to pay a designated amount of money for the resource. ${ }^{74}$

Finding that the Department of the Interior decided to adopt contingent valuation "intelligently and cautiously," 75 the court upheld its adoption as "reasonable and consistent with congressional intent, and therefore worthy of deference."76

The legal issue facing the Ohio court was obviously quite different from the jurisdictional problem of standing. Because of these divergent legal settings, the rejection of nonuse values in Defenders did not preclude their acceptance in Ohio. In particular, because individuals' nonuse valuations are used to measure a CERCLA recovery on behalf of the government rather than one paid to individuals, both cases leave the government, rather than private individuals, with the responsibility to protect nonuse values. ${ }^{77}$ Nevertheless, the two cases reflect different views of the world. Under Defenders, harm to nonuse value does not rise to the level of "injury in fact," while under Ohio, the same harm may

71. For a full discussion of the statute, see Douglas R. Williams, Valuing Natural Environments: Compensation, Market Norms, and the Idea of Public Goods, 27 ConN. L. REv. 365, 379-98 (1995).

72. Oil Pollution Act of 1990, §1006(d)(1), 33 U.S.C. $\S 2706$ (d)(1) (1994). The Act provides that the measure of natural resource damages is the restoration cost, plus the diminution in value of the resource pending restoration and the cost of assessing the damages.

73. 880 F.2d 432 (D.C. Cir. 1989).

74. Id. at 475 (footnotes omitted). For a more detailed discussion of the methodological issues concerning willingness to pay for public goods, see PER-OlOV JOHANSSON, THE ECONOMIC THEORY AND MeAsurement of ENVironmental BeneftTs 93-125 (1987).

75. Ohio, 880 F.2d at 476.

76. Id.

77. The govemment has standing in CERCLA cases because CERCLA specifically provides for the designation of federal and state "trustees" who have authority to assess damages and press claims for their recovery. 42 U.S.C. $\$ 9607(f)(2)$ (1994) (amended 1986). The Clean Water Act also contains a similar provision. \& 311,33 U.S.C. \& 1321 (1994). 
result in millions of dollars of liability. ${ }^{78}$ Physical presence is the touchstone for standing, but not for natural resource valuation under CERCLA. In short, localism reigns in standing law, but not in cases involving damages for natural resources.

\section{Regulatory Authority and the Geographic NeXuS}

In Part I, we considered two contexts where courts assessed what kinds of individual interests count as "harm" for legal purposes. We saw that American judges have taken divergent views on whether a physical connection with a particular environment is necessary to legitimize an individual interest. The same problem also arises when collectives, such as nations, assert interests in environmental harms. Here, physical location is again crucial as we address the question: Does a government sometimes have "standing" to take action against environmental harms outside its own borders? Tribunals as diverse as GATT trade panels, the U.S. Supreme Court, and the European Court of Justice have grappled with this question. Though the legal settings are different from those considered in Part $\mathrm{I}$, we will find the same diverging views about localism and globalism.

\section{A. The Tuna-Dolphin Cases}

We begin with the highly publicized GATT disputes over U.S. efforts to protect dolphins on the high seas. Since GATT is unfamiliar to most American lawyers and environmental scholars, an introduction to its provisions is in order.

\section{GATT in a Nutshell.}

GATT, the General Agreement on Tariffs and Trade, is a formal international agreement that explicitly prohibits certain protectionist trade barriers. ${ }^{79}$ GATT, on a item by item basis, develops "tariff bindings" which serve as maximum tariff rates. ${ }^{80}$ Then, to prevent the subversion of the commercial opportunities created by tariff bindings, GATT adds prohibitions on most other forms of trade barriers. ${ }^{81}$ Article XX qualifies GATT's prohibitions, authorizing ex-

78. Plaintiffs in environmental disaster cases have also apparently made aggressive use of contingent valuation. Daniel S. Levy \& David Friedman, The Revenge of the Redwoods? Reconsidering Property Rights and the Economic Allocation of Natural Resources, 61 U. CHI. L. REv. 493, 506 \& n.66 (1994).

79. Oct. 30, 1947, 61 Stat. pt. 5, A3, 55 U.N.T.S. 187 [hereafter GATT].

80. Id. at art. II, 61 Stat. pt. 5 at A14, 55 U.N.T.S. at 200 . Tariff bindings are established by negotiation, and then recorded in individual country schedules. $l d$.

81. These codes are based on two main provisions. The first is the prohibition of discriminatory internal taxes and regulations under the so-called "national treatment" rule of GATT Article III. Id. at 61 Stat pt. 5 at A18, 55 U.N.T.S. at 206. The key provision of Article III is paragraph 4:

The products of the territory of any contracting party imported into the territory of any other contracting party shall be accorded treatment no less favorable than that accorded to like products of national origin in respect of all laws, regulations and requirements affecting their internal sale, offering for sale, purchase, transportation, distribution or use. . . .

Id. (current version at Protocol Modifying Part II and article XXVI of the General Agreement on Tariffs and Trade, Sept 14, 1948, 62 U.N.T.S. 80, 82). The second provision is the prohibition of non-tariff 
ceptions whenever widely accepted government regulatory objectives-such as health, safety, or law enforcement-are found to require trade barriers. ${ }^{82}$

Under GATT, if a regulatory measure explicitly distinguishes between foreign and domestic goods, the first question is whether the different treatment is "less favorable" to the foreign products. If so, the measure is a prima facie violation of GATT Article III, paragraph $4 .{ }^{83}$ Measures providing explicitly different treatment of foreign goods are subject to severe scrutiny under this test. Any difference that could sometimes result in less favorable treatment is enough to establish a violation. ${ }^{84}$ Once a measure is found to violate Article III, the enacting government may seek to defend the measure under Article XX. The Article XX defense is difficult to establish, for it places the burden on the enacting government to demonstrate each element of the claimed excuse. ${ }^{85}$

Although it is awkwardly designed to do so, GATT also reaches facially neutral measures that burden trade. ${ }^{86}$ The text of GATT seems to suggest an unduly rigid approach to facially neutral regulations. Once a regulation triggers Article III, only the arduous Article XX defenses are available. This heavy

restrictions under GATT Article XI paragraph 1. Id. at 61 Stat pt. 5 at A32, 55 U.N.T.S. at 224. The text of Article XI paragraph 1 , which is subject to several exceptions, provides quite simply and broadly,

No prohibitions or restrictions other than duties, taxes or other charges, whether made effective through quotas, import or export licenses or other measures, shall be instituted or maintained by any contracting party on the importation of any product of the territory of any other contracting party or on the exportation or sale for export of any product destined for the Id. territory of any other contracting party.

82. Article $\mathrm{XX}$ reads as follows:

Subject to the requirement that such measures are not applied in a manner which would constitute a means of arbitrary or unjustifiable discrimination between countries where the same conditions prevail, or a disguised restriction on international trade, nothing in this Agreement shall be construed to prevent the adoption or enforcement by any contracting party of measures: (a) necessary to protect public morals;

(b) necessary to protect human, animal or plant life or health;

...

(e) relating to the products of prison labour;

(f) imposed for the protection of national treasures of artistic, historic or archaeological value;

(g) Relating to the conservation of exhaustible natural resources if such measures are made effective in conjunction with restrictions on domestic production or consumption[.]

Id. at art. XX, 61 Stat. pt. 5 at A60, 55 U.N.T.S. at 262.

83. Id. at 61 Stat pt. 5 at A18, 55 U.N.T.S. at 206. For the text of this provision see note 81 supra.

84. A good example is a GATT panel's treatment of Section 337 of the United States Tariff Act of 1930. United States: Section 337 of the Tariff Act of 1930, GATT Doc. L6439, para. 5.13-.20, compiled in GATT: Basic INSTRUMENTS AND Selected Documents 3345 (36th Supp. 1990). Section 337 is a U.S. unfair competition statute that applies to imports only. The panel held that the short and fixed time limits for Section 337 adjudication, while not disadvantaging all foreign defendants, did accord them less favorable treatment. This remained so even though some defendants might find that other advantages outweigh this disadvantage. Id. at para. 5.19. Differential treatment is thus a badge of potential discrimination and places a measure into a suspect category in which any harmful commercial effect constitutes a prima facie violation.

85. For a discussion of the general importance of such burden-of-proof standards to GATT decision making, see Robert E. Hudec, ENForcing International Trade Law: The Evolution of the MODERN GATT LEGAL SYSTEM 267-68 (1993).

86. For example, countries may place a different tax or regulatory burden on products with certain characteristics; however, it just happens that all or most foreign products fall into the disadvantaged category. See GATT, supra note 79, art. III, para. 1, 61 Stat pt. 5 at A18, 55 U.N.T.S. at 204. 
burden may be appropriate for cases of explicit discrimination but seems too harsh for regulations that merely burden trade. But GATT tribunals have found a way to avoid the inflexible application of Article III, so that facially neutral regulations often may avoid analysis under the rigorous Article XX standards. This approach was established in a GATT decision regarding variations in wine taxes. It provides that two items are not "like products," and hence can be treated differently without violating Article III, when the tribunal finds a legitimate regulatory difference between them. ${ }^{87}$

The recent Corporate Average Fuel Economy (CAFE) decision extensively discussed this GATT doctrine. ${ }^{88}$ The CAFE panel endorsed the Mississippi wine tax approach, under which likeness turns on whether the regulatory distinction was made "so as to afford protection to domestic production." 89 The panel defined this phrase as involving both the intent and the effect of manipulating "competitive opportunities in favor of domestic products." 90 Applying this two pronged test, the panel determined that for purposes of a luxury tax, cars costing more than $\$ 30,000$ were "unlike" cars with lower price tags. ${ }^{91}$ Similarly, cars with high gasoline consumption, for purposes of a "gas guzzler" tax aimed at reducing gasoline consumption, were "unlike" more efficient cars. 92

In short, GATT seems to have settled on a bifurcated approach to regulate laws that discriminate against foreign products. Facially discriminatory trade barriers are a prima facie violation of Article III, and the enacting government carries the heavy burden of proving an Article XX justification. But if a regulation merely has a disparate impact on foreign producers, they carry the burden of attacking the legitimacy of the regulation. Regardless of who has the burden of proof, whether a trade restriction can legitimately serve to protect the foreign environment remains unclear.

87. United States: Measures Affecting Alcoholic and Malt Beverages, GATT Doc. DS23/R (1992), paras. 5.70-.72, compiled in GATT: BASIC INSTRUMENTS AND SELECTED DOCUMENTS 206 (39th Supp. 1990) (rejecting interpretation of Article III's failure to distinguish between like and unlike products which had the effect of interfering with the regulatory authority and domestic policy options of contracting parties).

88. General Agreement on Tariffs and Trade Dispute Settlement Panel Report on United StatesTaxes on Automobiles, 33 I.L.M. 839 (1994) [hereinafter CAFE].

89. Id. at para. 5.8 .

90. Id. at para. 5.10 .

91. Id. at paras. 5.12-.16.

92. Id. at paras. 5.17-.38. In determining the aim of the luxury tax, the panel seemingly gave little weight to legislative history that strongly suggested protectionist motives. Id. at para. 5.12. Instead, the panel emphasized that the apparent aim of the legislation was to raise revenue by means of a luxury tax, a widely used measure in many countries. Id. Moreover, the panel noted that the $\$ 30,000$ level identified the upper end of the automobile market. Id.

The panel noted that the proportion of foreign and domestic cars selling below and above this threshold was unclear, particularly since non-EC imports might be affected differently. Id. at para. 5.12. As to the effect prong of the test, the panel noted that a high selling price did not appear to be "inherent" to EC or other foreign automobiles, and that EC, U.S., and Japanese manufacturers could and did manufacture cars on both sides of the threshold. Id. at para. 5.14. In addition, the panel found that the threshold did not appear "arbitrary or contrived in the context of the policies pursued." Id. The analysis of the gas guzzler tax followed similar lines. See id. paras. 5.17-.38. 


\section{Tuna-Dolphin $I$.}

In Tuna-Dolphin $I,{ }^{93}$ the first GATT decision that addressed extraterritorial environmental restrictions, the tribunal examined the U.S. Marine Mammal Protection Act (MMPA). The MMPA regulates fishing by the U.S. fleet in the interests of protecting dolphins and other marine mammals. ${ }^{94}$ In particular the statute contains provisions requiring special precautions in the eastern Pacific to avoid killing dolphins that are often caught along with tuna in purse-seine nets.

The MMPA is relevant to GATT only because it also imposes conditions on tuna caught by other nations. The U.S. cannot import tuna from a nation if the average number of dolphins killed by that nation's fleet during a given period exceeds 1.2 times the number the American fleet killed during the same period. ${ }^{95}$ To further ensure the safety of dolphins, the "Dolphin Safe" label can only be used on consumer products under certain conditions, regardless of whether the tuna was caught by American or foreign vessels. ${ }^{96}$

In 1990, following a U.S. ban on Mexican tuna pursuant to the MMPA, Mexico filed a GATT complaint challenging the fishing restrictions and the labeling requirement. The Tuna-Dolphin I panel held that the embargo did violate GATT, but upheld the MMPA's labeling requirement.97

The panel's analysis of the embargo found a prima facie violation of Article III, because the United States distinguished between two otherwise identical products - tuna caught in compliance with the MMPA and other tuna. ${ }^{98}$ Article $\mathrm{II}$ therefore required the United States to give Mexican tuna equally favorable treatment "whether or not the incidental taking of dolphins by Mexican vessels correspond[ed] to that of United States vessels."99

Note the use of the "like product" standard to screen regulations. The highly formalistic treatment of this standard in Tuna-Dolphin I, seems inconsistent with the more functional approach taken in the wine tax and CAFE cases. The panels in those cases attempted to distinguish bona-fide and protectionist regulations rather than focusing on the physical characteristics of the product. True, the dolphin-safe nature of the tuna is not a physical attribute of the product, but then neither is the retail price, which the CAFE panel found to be a valid product delineator. ${ }^{100}$

93. Tuna-Dolphin I, supra note 2.

94. Pub. L. No. 92-522, 86 Stat. 1027 (1972) (codified in scattered sections of 16 U.S.C.). This Act was subsequently amended in 1988 and again in 1990. Pub. L. No. 100-7111, 102 Stat. 4755 (1988) (codified in scattered sections of 16 U.S.C.); Pub. L. No. 101-627, 104 Stat. 4467 (1990) (codified in scattered sections of 16 U.S.C.).

95. U.S. Marine Mammal Protection Act Amendments of 1988, § 101(a)(2)(B) (1990).

96. Dolphin Protection Consumer Information Act, Pub. L. No. 101-627, § 900, 104 Stat. $4465-$ 67 (1995) (codified in part at 16 U.S.C. \$ 1385 (1995)).

97. Tuna-Dolphin I, supra note 2, at paras. 7.1, 7.3.

98. Id. at para. 5.15. The panel did not rely on the differences between the standards for domestic and imported nuna, which Mexico had alleged were discriminatory. Id. at paras. 5.15-.16.

99. Id. at para. 5.15.

100. See CAFE, supra note 88, at paras. 5.12-.16. A recent panel opinion seemingly takes the view that "likeness" is determined by the physical characteristics of the product. United States: Standards for Reformulated and Conventional Gasoline, World Trade Organization Doc. DS2/r (Jan. 17, 
The panel then considered whether the embargo on Mexican tuna could be justified under Article XX as a measure to protect animal life or health under subsection (b) or as a measure to conserve an exhaustible natural resource under subsection $(\mathrm{g}) .{ }^{101}$ The panel rejected the Article XX claims on two grounds. First, since the United States had not exhausted the possibility of international negotiation, and because the panel believed the MMPA contained discriminatory features that were superfluous to its asserted goals, the panel held that the measure failed the necessity requirement of Article XX.102 This justification was not implausible and probably would have sparked little debate.

The second ground, however, proved highly controversial. ${ }^{103}$ The panel concluded that Article XX did not allow extraterritorial environmental protection-that is, it adopted a strictly localist interpretation of Article XX. ${ }^{104}$ The panel based its conclusion in part on the intent behind Article $\mathrm{XX}^{105}$ and to a greater extent on policy considerations:

The Panel considered that if the broad interpretation of Article XX(b) suggested by the United States were accepted, each contracting party could unilaterally determine the life or health protection policies from which other contracting parties could not deviate without jeopardizing their rights under the General Agreement. The General Agreement would then no longer constitute a multilateral framework for trade among all contracting parties but would provide legal security only in respect of trade between a limited number of contracting parties with identical internal regulations. ${ }^{106}$

The premise of this argument was that the underlying domestic regulation would not be subject to any scrutiny at all under Article XX, which would allow consideration only if the trade measure was necessary to enforce the do-

1996) (on file with the author). In concluding that imported and domestic gasoline were like productsa point conceded by the parties-the panel remarked that "chemically-identical imported and domestic gasoline by definition have exactly the same physical characteristics, end-uses, tariff classification, and are perfectly substitutable." Id. at para. 6.9. The panel therefore concluded that the two were like products. Id. The panel had previously referred to a definition of product similarity based on end-uses, " "consumers" tastes and habits, which change from country to country," and the product's properties, nature and quality. Id. at para. 6.8. The challenged air pollution regulation set different baseline for gasoline composition for domestic and certain imported gasoline, purportedly because of the inadequacy of baseline data from foreign producers. The panel said that distinctions based on the identity of the producer, regardless of the reasons for making the decision, were inappropriate under Article III because they would expose imported goods to "a highly subjective and variable treatment according to extraneous factors," which in turn would "create great instability and uncertainty" in competitive conditions. Id. at para. 6.11. All of this discussion, however, can reasonably be classified as dictum since the likeness of the products was not in dispute. The outcome of the case really turned on the validity of the Article XX defense, which was rejected because of the availability of less-restrictive alternatives. Id. at para. 6.24-.29. The panel's decision was affirmed on the latter ground. United States: Standards for Reformulated and Conventional Gasoline, AB-1996-1 (Apr. 29, 1996).

101. Tuna-Dolphin $l$, supra note 2 , at paras. 5.22-.23.

102. Id. at para. 5.28 .

103. See C. Ford Runge, François Ortalo-Magne \& Philip Vande Kamp, Freer Trade, Protected Environment: Balancing Trade Liberalization and ENvironmental Interests 71 (1994) (stating that the Tuna-Dolphin I dispute is "[p]erhaps the most divisive and inflammatory" instance of trade-environment conflict).

104. Tuna-Dolphin I, supra note 2, at paras. 5.24-.26, 5.31.

105. Id. at para. 5.26.

106. Id. at para. 5.27. The panel's analysis of Article XX(g) was similar. See id. at para. 5.32. 
mestic standard. ${ }^{107}$ Hence, according to the panel, the underlying standard itself would be immune from scrutiny, so that any difference whatsoever in product standards could become the basis for an embargo. ${ }^{108}$

In contrast to its brusque rejection of the embargo, the panel accepted the second restriction, allowing only tuna that complied with certain requirements to receive the "dolphin safe" label. The panel considered only the application of the most general GATT standard, the requirement of "most favored nation" treatment. ${ }^{109}$ The panel found that the labeling rules merely provided consumers with additional information and made a reasonable distinction based on the location of the catch. ${ }^{110}$ Oddly enough, the panel failed to discuss the validity of the labeling requirement under Article III, as raised by Mexico. ${ }^{111}$

Despite this sop to environmental sensitivities, the panel's decision was extremely controversial-enough so that Mexico decided not to seek official adoption of the decision for fear of derailing then-ongoing NAFTA negotiations. ${ }^{112}$

\section{Tuna-Dolphin II.}

Within a few years, another GATT panel revisited the extraterritoriality issue. Tuna-Dolphin II dealt with the secondary-boycott provisions of the MMPA. ${ }^{113}$ Originally, U.S. administrative agencies interpreted these provisions to impose only a certification requirement for imports from intermediary nations-those purchasing tuna from noncompliant fishing nations. The certificate attested that the shipment did not contain tuna harvested with the use of purse seines from the eastern Pacific. But U.S. courts rejected this administrative interpretation of the Act. Instead, the courts read the Act to prohibit all tuna imports from intermediary countries. ${ }^{114}$ As a result of this judicial interpretation, the European Community and the Netherlands separately initiated proceedings against the United States under GATT.

107. Id.

108. For a critique of this argument, see Richard B. Stewart, International Trade and Environment: Lessons from the Federal Experience, 49 WASH. \& LEE L. REv. 1329, 1366-67 (1992). See also Steve Charnovitz, Green Roots, Bad Pruning: GATT Rules and Their Application to Environmental Trade Measures, 7 TUL. ENVTL. L. J. 299, 335-43 (1994) (critiquing the panel's argument). The distinction between the trade measure and the underlying regulation was unusually easy to draw in TunaDolphin I, which involved an explicit embargo. This distinction would have been much more difficult to draw if the statute had merely banned the sale of dolphin-unsafe tuna regardless of origin. Such a statute could, under the Mississippi wine and $C A F E$ cases, receive a much more sensitive analysis under the "like product" standard. As those cases illustrate, GATT has the capability to consider the bona fide aims and effects of domestic regulations when so inclined. See notes 87-92 and accompanying text.

109. Tuna-Dolphin I, supra note 2, at paras. 5.41-.44

110. Id. at para. 5.42 .

111. See id. at para. 3.4 (stating that Mexico requested examination of the labeling requirement under Article III of the General Agreement).

112. For a discussion of the debate over the decision and the later negotiations between Mexico and the United States, see David Vogel, TRADING Up: Consumer and ENVIRONMENTAL: Regulation in a Global ECONOMY 117-23 (1995).

113. See General Agreement on Tariffs and Trade: United States-Restrictions in Imports of Tuna, 33 I.L.M. 1397, at paras. 1.3-.4 (1994) [hereinafter Tuna-Dolphin II].

114. Earth Island Inst. v. Mosbacher, 785 F. Supp. 826, 832-33 (N.D. Cal. 1992), vacated by Earth Island Inst. v. Brown, 17 F.3d 1241 (9th Cir. 1994). 
The GATT panel upheld the challenge to this prohibition but rejected the Tuna-Dolphin I holding regarding extraterritoriality. It agreed with the earlier panel that Article III calls for "a comparison between the treatment accorded to domestic and imported like products, not for a comparison of the policies or practices of the country of origin with those of the country of importation."115 In its Article XX analysis, however, it parted company with the earlier panel, holding that Article XX could apply to the extraterritorial protection of life forms and natural resources. ${ }^{116}$ Unlike the first panel, the second found nothing in GATT's text or drafting history to preclude this interpretation. ${ }^{117}$ It cited previous panels that had applied Article $\mathrm{XX}(\mathrm{g})$ to migratory fish without focusing on the location of the catch. ${ }^{118}$ Furthermore, the panel noted that other provisions of Article XX-such as the provision allowing embargoes of products made by prison labor-were inconsistent with the view that GATT "proscribed in an absolute manner measures that related to things or actions outside the territorial jurisdiction of the party taking the measure." 119 Thus, the panel apparently would have upheld the use of certification to prevent imports of specific fish caught in violation of U.S. regulations.

The panel was unwilling to take the further step of upholding a blanket ban based simply on country of origin, especially when the ban's purpose was to pressure other nations to change domestic policy. The panel explained the distinction as follows:

If Article XX(b) were interpreted to permit contracting parties to deviate from the basic obligations of the General Agreement by taking trade measures to implement policies within their own jurisdiction, including policies to protect living things, the objectives of the General Agreement would be maintained. If however Article XX(b) were interpreted to permit contracting parties to impose trade embargoes so as to force other countries to change their policies within their jurisdiction, including policies to protect living things, and which required such changes to be effective, the objectives of the General Agreement would be seriously impaired. ${ }^{120}$

The panel thus concluded that measures taken to pressure other nations to change their policies could not meet the necessity test under Article XX(b). ${ }^{121}$

Tuna-Dolphin II was a substantial step away from the first panel's localist approach. Despite this, the reception of Tuna-Dolphin II has been mixed. Steve Charnovitz, a leading critic of the first decision, commended the second panel's willingness to brave strong opposition from the trade policy community. ${ }^{122}$ Nevertheless, he found Tuna-Dolphin II "unconvincing in its application of historical precedent, GATT negotiating history, and the facts of the

115. Tuna-Dolphin II, supra note 113, at para. 5.8 (emphasis added).

116. Id. at paras. 15.15-.17.

117. Id. at para. 15.15 .

118. Id.

119. Id. at para. 15.16 .

120. Id. at para. 5.38.

121. Id. at para. 5.39. For the similar analysis under Article XX(g), see id. at paras. 5.26-.27.

122. Steve Chamovitz, Dolphins and Tuna: An Analysis of the Second GATT Panel Report, 24 ENUT'L LAw Rep. 10,567, 10,579 (1994). 
dispute."123 Charnovitz disagreed with the perception that Tuna-Dolphin II represented significant progress, and instead asked whether the decision was a sign of fundamental flaws in GATT's adjudicatory process. ${ }^{124}$ Clearly, the final word on extraterritorial regulation under GATT has yet to be written.

\section{B. The Geographic Nexus in Common Markets}

Analogs to the Tuna-Dolphin problem have arisen in other free trade regimes. The United States and the European Union (EU) have judicially enforceable prohibitions on internal trade barriers. Both have also addressed the question of whether a government can burden trade to prevent environmental harm outside its own borders. The responses of the Supreme Court and the European Court of Justice (ECJ) to these issues help place both Tuna-Dolphin cases in perspective.

\section{The Dormant Commerce Clause.}

The "Dormant Commerce Clause" doctrine places implicit limits on state regulations that impact trade. ${ }^{125}$ Because it is familiar ground for many readers, a brief review of this doctrine should suffice. ${ }^{126}$

The current doctrine distinguishes three categories of cases. The first category consists of state statutes which facially discriminate against out-of-state commerce. These measures are subject to strict scrutiny. ${ }^{127}$ A second category involves facially neutral statutes with a "discriminatory effect." For these measures to survive a Commerce Clause challenge, the state has the burden of justifying the regulation in terms of its benefits and the unavailability of nondiscriminatory alternatives. ${ }^{128}$ The third category involves regulations that place "incidental" or "indirect" burdens on commerce. The Court applies a balancing test to such statutes. ${ }^{129}$

The tidiness of this three-part scheme is somewhat deceptive. In reality, the categories remain ill defined. A recent decision, for example, casually lumps together the first two categories as involving statutes that "clearly discrimi-

123. Id. at 10,582 .

124. Id.

125. For a more extensive doctrinal review, see Winkfield F. Twyman, Jr., Beyond Purpose: State Discrimination in Interstate Commerce, 46 S.C. L. REv. 381, 382-409 (1995).

126. For a more comprehensive analysis of U.S. law and its relationship to GATT, see Daniel A. Farber and Robert E. Hudec, Free Trade and the Regulatory State: A GATT's-Eye View of the Dormant Commerce Clause, 47 VAND. L. Rev. 1401 (1994).

127. The leading case is City of Philadelphia v. New Jersey, 437 U.S. 617, 626-29 (1978), which invalidated a state statute that treated out of state waste differently because of its origin.

128. See Hunt v. Washington State Apple Advertising Comm., 432 U.S. 333, 353-54 (1977) (holding that North Carolina's facially neutral labeling statute violated the Commerce Clause due to its discriminatory effect, failure to eliminate the problems it was designed to combat, and the ample availability of nondiscriminatory alternatives).

129. See Pike v. Bruce Church, Inc., 397 U.S. 137, 142, 146 (1970) (holding state statute that incidentally burdens commerce will be upheld unless the burden imposed on such commerce is clearly excessive in relation to local benefits). Professor Stewart reads the Court's rationale in this area as establishing a deferentially applied "standard of net proportionality." Stewart, supra note 108, at 1336. 
nate[ ]."130 Similarly, the Court itself has observed that the line between the second two categories is permeable. ${ }^{131}$ Moreover, difficulties arise in the application of this three-part test. Kassel v. Consolidated Freightways Corp is a classic example of the more lenient balancing test. ${ }^{132}$ This seemingly straightforward challenge to an Iowa truck regulation, ${ }^{133}$ however, produced a fractured Court. ${ }^{134}$ The plurality struck down the regulation after applying a balancing test because it found essentially no evidence of any safety benefit to offset the regulatory burden. ${ }^{135}$ Two concurring Justices rejected even this limited use of a balancing test where safety is involved, but concluded that the statute was "protectionist in nature" and thus impermissible under the Commerce Clause. ${ }^{136}$ The dissenters, on the other hand, also applied a balancing test, but found that the statute was a valid safety regulation. ${ }^{137}$

A more recent environmental decision demonstrates the Court's difficulties in applying the Dormant Commerce Clause have not abated. In $C \& A C a r$ bone Inc. v. Town of Clarkstown, the local government employed a flow control ordinance requiring that all waste generated within the town go to a government financed disposal facility. ${ }^{138}$ The Court divided five to four on whether to consider the ordinance discriminatory against out-of-state disposal sites, or whether to use the more lenient balancing test. Ultimately, the Court found that the ordinance was discriminatory. 139 To add to the confusion, one of the four Justices who advocated an application of the balancing test thought the ordinance failed that test, ${ }^{140}$ while the remaining three believed the ordinance was justifiable on the basis of its legitimate benefits. ${ }^{141}$

The most significant aspect of Carbone for present purposes is its brief discussion of the extraterritoriality issue. ${ }^{142}$ Flow control is designed to prevent waste from being diverted to cheaper, but less environmentally sound, disposal sites. Justice Kennedy's opinion for the Court rejected this justification for the ordinance because of the availability of nondiscriminatory alterna-

130. Fort Gratiot Sanitary Landfill, Inc. v. Michigan Dep't of Natural Resources, 504 U.S. 353, 359 (1992) (discussing facially neutral statute with discriminatory effect in same vein as a facially discriminatory statute).

131. "[T]here is no clear line separating the category of state regulation that is virtually per se invalid under the Commerce Clause, and the category subject to Pike v. Bruce Church balancing approach." Brown-Forman Distillers Corp. v. New York State Liquor Auth., 476 U.S. 573, 579 (1986).

132. 450 U.S. 662 (1981).

133. The case involved an lowa regulation banning all semi-trucks over a certain size. Since neighboring states allowed such trucks, the regulation added significantly to the trucking companies' transportation costs. Id. at 674.

134. Justice Powell, joined by three other Justices, announced the judgment of the Court. Justice Brennan, joined by Justice Marshall, wrote a separate opinion concurring in the judgement only.

135. Id. at 678-79.

136. Id. at $681-85$ (Brennan, J., concurring in the judgment).

137. Id. at 693-96 (Rehnquist, J., dissenting).

138. 114 S. Ct. 1677 (1994).

139. Id. at 1682 .

140. Id. at $1689-90$ ( $\mathrm{O}^{\prime}$ Connor, J., concurring) (arguing that the ordinance could achieve its ends by other less restrictive means).

141. Id. at 1702 (Souter, J., dissenting) (maintaining that the ordinance is justified by its "legitimate benefits in reliable and sanitary trash processing").

142. Id. at 1683 . 
tives. Of these alternatives, the "most obvious would be uniform safety regulations enacted without the object to discriminate."143 Such regulations would ensure that the municipal facility's competitors "do not underprice the market by cutting corners on environmental safety." 144 This remark suggests that the county could legitimately restrict disposal of local waste to environmentally safe sites, whether those sites are located in the county or elsewhere. Thus, the county seemingly could prohibit waste shipments to environmentally questionable disposal sites in other states in order to prevent unfair competition by inferior facilities.

The Court seemed to endorse a more localist approach, however, in the next three sentences:

[The town may not] justify the flow control ordinance as a way to steer solid waste away from out-of-town disposal sites that it might deem harmful to the environment. To do so would extend the town's police power beyond its jurisdictional bounds. States and localities may not attach restrictions to exports or imports in order to control commerce in other states. ${ }^{145}$

By the same token, presumably a state could not use a ban on imported products to protect an endangered species, or apply a ban on exports to prevent the sale of dangerous products.

While this passage seems to endorse a purely localist approach, the Court's earlier sentence suggests that a state has a legitimate interest in maintaining a "level playing field" regarding environmental costs. The level playing field rationale is conceptually distinct from globalist environmental concerns, but may have similar practical implications. On balance, the Court's hurried remarks in Carbone seem unlikely to satisfy either environmentalists or free traders. Although the Court seems inclined toward localism, Carbone can hardly be regarded as a definitive statement on the issue.

\section{European Community Law.}

The issue of extraterritoriality has also arisen under the European Community's rules analogous to the Dormant Commerce Clause. An understanding of the European Court of Justice's approach to the issue requires some background regarding the legal scheme.

European Community trade rules address the same problems as GATT and the Dormant Commerce Clause. ${ }^{146}$ Article 30 of the Treaty of Rome prohibits "[q]uantitative restrictions on imports and all measures having equivalent ef-

143. Id.

144. Id.

145. Id.

146. Treaty Establishing European Economic Community, art. 30, opened for signature March 25 , 1957, art. 30, 298 U.N.T.S. 11, 26; see generally GEORGE A. BERMAN, ROGER J. GOEBEL, WIILIAM J. Davey \& Eleanor M. Fox, Cases and Materials on European Community Law 317-95 (1993) (discussing the community's approach to the free market of goods within the internal market); Josephine Steiner, European Economic Community Law 81-105 (3d ed. 1992) (discussing trade difficulties facing the EEC). 
fect."147 This provision has been construed very broadly. The leading case defines Article 30 as encompassing "[a]ll trading rules enacted by Members States which are capable of hindering, directly or indirectly, actually or potentially, intra-Community trade." 148 This definition seems to embrace virtually all commercial regulation. ${ }^{149}$ The ECJ has used Article 30 quite aggressively in battering down local restrictions on products; its general rule is that a product that can be marketed legally at home can be marketed legally anywhere in the EU. ${ }^{150}$

The EEC Treaty contains an exception to the general rule of Article 30. Article 36 allows trade restrictions "justified on grounds of public morality, public policy or public security; the protection of health and life of humans, animals or plants; the protection of national treasures possessing artistic, historic or archaeological value; or the protection of industrial and commercial property." 151 Article 36 adds, however, that such restrictions shall not "constitute a means of arbitrary discrimination or a disguised restriction on trade between Member States." 152 In a key ruling, the ECJ expanded the scope of justified government interests beyond those explicitly listed in Article 36. This case, commonly known as Cassis de Dijon, adopted a "rule of reason" approach to Article 30.153

The leading environmental case is Commission v. Denmark, ${ }^{154}$ the Danish Beer case, which applied the "rule of reason" approach. ${ }^{155}$ Denmark had passed a law mandating the recycling of beer and soda bottles and limiting the types of bottles sold to those most easily recycled. ${ }^{156}$ Compliance was far easier for Danish than for foreign firms. ${ }^{157}$ Despite this, the ECJ declared the reuse requirement "an indispensable element of a system." 158 It declared that

147. Treaty Establishing the European Economic Community, supra note 146, art. 30, 298 U.N.T.S. at 26. (1974).

148. Case 8/74, Procureur du Roi v. Dassonville, 1974 E.C.R. 837, 837, 2 C.M.L.R. 436, 453-54

149. The ECJ has, however, drawn the line at nondiscriminatory restrictions on retail selling such as Sunday closing laws, even though these laws may diminish the sales of imported, as well as local, products. Case C-145/88, Torfaen Borough Council v. B \& Q plc, 1989 E.C.R. 3851, 3882, 1 C.M.L.R. 337, 359-60 (1990). The fact that the ECJ heard this case signals the broad scope of Article 30; it is unlikely that anyone would seek Supreme Court review of Sunday closing laws under the Dormant Commerce Clause.

150. See, e.g., Case 407/85, 3 Glocken v. USL Centro-Sud, 1988 E.C.R. 4233 (striking down Italian requirements for pasta content); Case 178/84, Commission v. Germany, 1987 E.C.R. 1227, [1987-1988 Transfer Binder] Common Mkt. Rep. (CCH) II 14,417 (1987) (striking down German product definition for beer as protectionist legislation).

151. Treaty Establishing the European Economic Community, supra note 146, art. 36, 298 U.N.T.S. at 26.

152. Id.

153. Case 120/78, Rewe-Zentral AG v. Bundesmonopolverwaltung Für Branntwein, 1979 E.C.R. 649, 668-69, 3 C.M.L.R. 494, 498-500 (1979).

154. Case 302/86, 1988 E.C.R. 4607, I C.M.L.R. 619 (1989).

155. For an overview of environmental law and policy in the European Community, see Richard B. Stewart, Environmental Law in the United States and the European Community: Spillovers, Cooperation, Rivalny, Institutions, 1992 U. CHI. LEGAI F. 41, 51-61.

156. Denmark, 1988 E.C.R. at 4619,1 C.M.L.R. at 622.

157. 1988 E.C.R. at 4631,1 C.M.L.R. at 631.

158. Id. 
environmental protection is "'one of the Community's essential objectives' "159 which could therefore serve to limit Article 30.160 The Court upheld the reuse requirement because the restrictions it placed on foreign goods "cannot be regarded as disproportionate," given the aims of the legislation. ${ }^{161}$ The Court struck down the bottle specifications, however, because they added little environmental protection to that already provided by the reuse rule, and hence were disproportionate in their effect on trade. ${ }^{162}$

With this background in mind, we can turn to the ECJ's ruling on extraterritoriality in the Dutch Grouse Case. ${ }^{163}$ Crudely put, the court held that the Netherlands could not ban local sales of birds killed legally in other member states, even though Dutch law protected the species. ${ }^{164}$ Both the facts and the holding, however, are more complex, for the ECJ's decision does not embrace either globalism or Tuna-Dolphin I's localism.

The defendant, Van den Burg, had been prosecuted for the sale of red grouse at a store in the Hague. Dutch law prohibits the sale of birds found anywhere in the wild in Europe. ${ }^{165}$ The defendant sold a red grouse that had been legally killed in the United Kingdom, where the bird is plentiful. A European Community Council Directive bans the sale of certain birds entirely and limits sales for others, but does not cover the red grouse. ${ }^{166}$ The conservation directive, however, sometimes allows member states to enact stricter regulations for conservation purposes. ${ }^{167}$ Such local measures must conform to some restrictions, including requirements that they be consistent with Article 36 and that they "in no case stem from commercial policy considerations." 168

In portions of his advice to the court, ${ }^{169}$ the EEC Advocate General supported a localist approach to the case:

An important question is whether Article 36 can also apply in a case such as this, involving the adoption by a Member State of a measure for protecting against hunting animals found not within its territory but in another Member State. ... It is true that Article 36 does not expressly state that the interests which it protects must be located in the legislating Member State. Nevertheless, it would seem still less appropriate to regard that article as an encouragement to adopt legislation for the protection of interests located in other Member States. Moreover, a measure unilaterally adopted by one Member State in connection with the hunting of animals in another Member State would

159. 1988 E.C.R. at 4630, 1 C.M.L.R. at 630 (quoting Case 240/83, Procureur de la Republique v. Association de Defense des Bruleurs D'Huiles Usagees, 1985 E.C.R. 531)

160. Id.

161. Id.

162. 1988 E.C.R. at 4632,1 C.M.L.R. at 632.

163. Case C-169/89, Criminal Proceedings against Van den Burg, 1990 E.C.R. I-2143.

164. Id. at $\mathrm{I}-2165$.

165. Id. at $\mathrm{I}-2146$.

166. Id. at $\mathrm{I}-2164$

167. Id. at $\mathrm{I}-2145$.

168. Id.

169. For a discussion of the role of the Advocate General in ECJ proceedings, see Kevin Andrew Swartz, Note, Powerful, Unique, and Anonymous: The European Court of Justice and Its Continuing Impact on the Formation of the European Community, 3 S. CAL. INTERDISCIPLINARY L. Rev. 687, 69192 (1994). 
seem at first sight to be difficult to reconcile with the principle of mutual confidence between Member States . . . 170

One can easily observe a strong resonance with Tuna-Dolphin I in this passage.

The Advocate General's opinion, however, extends beyond this passage. He favored the argument that the directive supplied a legitimate basis for applying Article 36 because of its recognition of the "transfrontier nature of the protection of birds." "171 The remainder of his opinion applies the requirements of necessity and proportionality under Article $36 .{ }^{172}$ He concluded that the Dutch had failed to carry the burden of proof in this regard:

[A]nother Member State must be able to adduce powerful reasons before it can be assumed that a prohibition on imports, that is to say a breach of the fundamental principle of the free movement of goods, constitutes ... the least restrictive measure for the conservation of a bird species occurring in [another] Member State."173

Because of the minimal contribution that a Dutch ban would make to encouraging conservation in Great Britain, he considered the conservation benefits disproportionate with the costs of an absolute prohibition on trade. ${ }^{174}$ These arguments implicitly seem to accept the legitimacy of Holland's goal of protecting British grouse.

The judgment of the ECJ itself is even less clearly localist. Focusing its analysis on the Community Directive, the court held that it allowed member states to adopt stricter conservation measures only for species inhabiting their own territory or for migratory or endangered species listed in the Directive. ${ }^{175}$ Consequently, the court delivered the following judgment:
Article 36 of the Treaty, read in conjunction with Council Directive 79/409/ EEC of 2 April 1979 on the conservation of wild birds, must be interpreted as meaning that a prohibition on the importation and marketing cannot be justified in respect of a species of bird which does not occur in the territory of the legislating Member State but is found in another Member State where it may lawfully be hunted under the terms of that directive and under the legislation of that other State, and which is neither migratory nor endangered within the meaning of the directive. ${ }^{176}$

For the reader who is familiar with the United States courts, the most interesting aspect of the ECJ's judgment and the Advocate General's opinion is their fluid shifting between statutory preemption and dormant commerce clause analysis. United States courts typically ignore any federal statute when analyzing regulations under the Dormant Commerce Clause. Unless a federal statute directly authorizes the state legislation in question, no significance attaches to the fact that a state law is consistent with the general federal regulatory

170. Van den Burg, 1990 E.C.R. at I-2154 to 55.

171. Id. at $\mathrm{I}-2155$.

172. Id. at $\mathrm{I}-2154$ to 59 .

173. Id. at $\mathrm{I}-2157$.

174. Id. at $\mathrm{I}-2159$.

175. Id. at $\mathrm{I}-2163$ to 64.

176. Id. at $\mathrm{I}-2165$. 
scheme. ${ }^{177}$ Van den Burg thus suggests the possibility of a more creative utilization of statutory materials to inform free trade decisions. In particular, the Advocate General's opinion suggests that perhaps a tribunal should not consider the legitimacy of extraterritorial regulatory interests in a vacuum, but should instead consider multilateral recognition of those interests.

\section{The Evolving Geographic Nexus}

\section{A. Three Approaches to the Nexus Issue}

We have seen various tribunals grapple with the geographic nexus issue in a wide range of legal settings. Having captured these specimens of judicial reasoning, we now categorize and label our collection. Roughly speaking, we can divide the judicial approaches into three categories: localist, globalist, and evolutionary. Each deserves a closer look.

\section{Localism.}

Localism focuses on physical presence as its core concern. An individual physically present in an area has a cognizable interest in its environment; just as governments have a legitimate interest in harms that are physically present within their territories. Tuna-Dolphin I is probably the best known example of this view. Its clearest expression, however, is most likely Justice Scalia's incredulous response to environmentalist claims in Defenders. ${ }^{178}$

At the international level, localism is surely the baseline. Despite all the painful movement toward a more cohesive international order in the past century, the idea of national sovereignty is still predominant in international law. Even within the United States, localism has a strong appeal, as evidenced by the recent resurgence of federalism. Presumably, American states serve the needs of their own communities, while cross-jurisdictional issues are best handled at the national level. At the individual level, an intuitive distinction exists between a person who is a "citizen," even temporarily, of the affected area, and a complete outsider who lacks any physical contact with the problem. Let each level of government, then, tend to its own internal concerns, while outsiders mind their own business. That is the localist creed, and it is not an unappealing one. ${ }^{179}$

Localism is ultimately unsustainable, however. Localist doctrines are set in a legal matrix that presumes some form of globalism. Consider, for example, Tuna-Dolphin I. At heart, the decision appeals to the deep-seated view that what the Mexicans do is their own business, so long as it does not take place in U.S. territory. That, after all, is the meaning of sovereignty. But environmentalists also appeal to national sovereignty. They justly argue that American

177. See City of Philadelphia v. New Jersey, 437 U.S. 617, 620-21, 621 n.4, 629 (1978) (determining that a state statute, despite the fact it is consistent with the federal scheme, is nevertheless unconstitutional).

178. See text accompanying notes 43-50 supra.

179. For some thoughts about the normative basis of localism, see LEA BRILMAYER, CONFICT OF LAws: CASEs and Materials 253-59 (4th ed. 1995). 
decisions about what kinds of tuna to allow on U.S. markets takes place within American territory, and are therefore none of Mexico's business. ${ }^{180}$ This rhetorical symmetry is not surprising: If Justice Blackmun had written GATT, he would have quoted John Donne in asserting that no economy is an island unto itself. ${ }^{181}$ GATT is based on a profoundly global world view, ${ }^{182}$ but emerging perceptions about international interdependence cannot readily be confined to economic matters.

Similarly, while governments such as American states may concern themselves primarily with their own internal affairs, they function as part of a broader community - otherwise, there would be no tribunal judging the impact of their actions on other members of the community. If they are responsible for the economic impact of their actions on other members of the community, they should also have some responsibility to consider other noneconomic interrelationships. If New Jersey must design its waste disposal laws to limit economic harm to other states, how can it then be foreclosed from also considering environmental harm to those states?

In short, environmental autarky conflicts with political and economic community. As legal regimes move toward recognition of other kinds of mutual interdependence, environmental localism becomes increasingly anomalous. The existence of transboundary communities inevitably creates a drive away from localism in all spheres.

Moreover, environmental interconnection has become too real to ignore. Even children are well aware of international environmental problems such as the greenhouse effect and the disappearing rain forest. What children know must also eventually come to the attention of judges. Perhaps more importantly, the legal system has become increasingly anti-localist. A host of international treaties, epitomized by the Rio Declaration, ${ }^{183}$ have come into force in the past two decades. As the GATT panel discovered, its embrace of localism in Tuna-Dolphin I put it on a collision course with popular measures such as the Convention on International Trade in Endangered Species (CITES). ${ }^{184}$ Within the United States, matters such as pollution, wetland preservation, and waste disposal are no longer left solely to local authorities. Indeed, the trend has been to single out environmental matters as peculiarly appropriate for nonlocal intervention, as in repeated amendments to the Treaty of Rome that have continually strengthened the EU's environmental regulatory powers. ${ }^{185}$ Underlying all of these developments is the recognition that environmental harms are

180. For a discussion of the conflicting sovereignty claims, see Chang, supra note 68, at 2193-94.

181. See text accompanying notes 17-20 supra.

182. See Barry Friedman, Federalism's Future in the Global Village, 47 VAND. L. REv. 1441, 1443-61 (1994) (discussing the internationalization of regulatory authority); see also Stewart, supra note 108 , at 1371 ("The economy is global.").

183. Rio Declaration on Environment and Development, U.N. Doc. A/conf.151/1 (1992).

184. Convention on International Trade in Endangered Species of Wild Fauna and Flora, opened for signature Mar. 3, 1973, 27 U.S.T. 1087, 993 U.N.T.S. 243.

185. See Stewart, supra note 155, at 47-51. "The Single European Act explicitly recognizes environmental protection as a distinct community objective' and adds a new Title XII to the Treaty entitled 'Environment'." Id. at 49. 
not purely local, but instead are very much the business of "outsiders." Although far from dead, localism has lost much of its authority in the environmental sphere.

Furthermore, maintaining a strong localist baseline quickly becomes complex and unmanageable. For example, GATT advocates recognize that the agreement must accommodate CITES and other multilateral actions. The most sophisticated efforts to carve out space for multilateralism within a localist GATT regime, however, have proven extraordinarily difficult. ${ }^{186}$ In standing law, Justice Scalia's effort at localism requires fine procedural distinctions and unexplained qualitative judgments to account for cases where the Court has adopted looser standing requirements. ${ }^{187}$ What starts out looking like a clean formal concept ends up in Byzantine knots.

Whatever its lingering attractions, localism's long-lasting viability seems dubious. Unfortunately, as we will see, difficulties also plague the leading alternative to localism.

\section{Globalism.}

The basic idea of globalism is that environmental concerns know no territorial boundaries. What happens in one place affects everyone everywhere, and no particular geographic nexus should be required as a basis for legal action. Justice Blackmun's invocation of John Donne stands as the clearest expression of globalism in American law. ${ }^{188}$ It may be aptly joined with Justice Stevens' analogy between transboundary environmental concerns and relationships with distant family members. ${ }^{189}$ Nothing in the international sphere reaches quite this level of rhetoric. Tuna-Dolphin II does, however, seem to leave unrestricted the kinds of environmental objectives that can be pursued under GATT, provided that trade measures are keyed to the specific goods rather than to national origin.

Like localism, globalism has a genuine appeal. It is difficult to avoid cliche in describing the integration of the world economy or the rapid globalization of information flows. With these developments comes a cosmopolitanism that makes localism seem pinched and provincial. Satellite photographs of the planet manifest its ecological unity and epitomize the appeal of globalism to environmentalists. If a long term future trend appears, it is likely to be in the direction of globalism.

Though globalism may lie in the future, nations, states, and local communities continue to command strong allegiance and to exercise most power in the

186. Robert E. Hudec, GATT Legal Restraints on the Use of Trade Measures Against Foreign Environmental Practices, in HARMONIzATION AND INTERNATIONAL TRADE 95 (Jagdish Bhagwati \& Robert E. Hudec eds., 1996).

187. Consider the distinctions drawn in Lujan v. Defenders of Wildlife, 504 U.S. 555 (1992), between (a) standing as an issue in the pleading stage and in the motion for summary judgment, $i d$. at 560-61; (b) direct versus third-party effects, id. at 561-62; (c) proof of the imminence of harm versus the extent of harm, id. at $564 \mathrm{n} .2$; and (d) procedural versus nonprocedural rights, id. at $572 \mathrm{n} .7$.

188. Sierra Club v. Morton, 405 U.S. 727, 760 n.2 (1972) (Blackmun, J., dissenting).

189. Defenders, 504 U.S. at 572 n.2 (1992). 
present. Indeed, it is far from clear that we should abandon local autonomy in favor of a centralized world government, even if that were a viable option. Thus, political reality now and in the foreseeable future dictates that local governments will continue to exist and to clash over environmental problems. Globalism lacks any intellectual apparatus for arbitrating these disputes, for it gives every government an equally legitimate concern with every issue.

In the absence of any system for allocating regulatory authority, globalism leaves raw political power as the ultimate source of authority. The United States claims an interest in how Mexico catches tuna; and under globalism, the only test of that claim is whether the United States has enough economic power to impose its will. Thus, from some perspectives, environmental globalism can be a kind of imperialism. ${ }^{190}$

Although transboundary environmental effects are common, local impacts are usually stronger. It may be true that everyone in the world has some interest in the state of the Sri Lankan elephant, but surely the Sri Lankans have the strongest interest in the issue. Not only do the Sri Lankans derive the greatest potential benefit from the elephants, but they are the ones who will inevitably bear much of the burden of environmental protection. A legal order which treats all interests as equally fungible improperly erases the particular concerns of local populations. After all, even Justice Douglas-no captive of legal traditionalism - saw a difference between the actual users of an area and well intentioned bystanders. ${ }^{191}$

\section{The Evolutionary Approach.}

Globalism and localism are both fundamentally incomplete. Each contains a partial normative vision that deemphasizes the values promoted by the other. ${ }^{192}$ A coherent approach to the geographic nexus must somehow give credence to both sets of values. If neither globalism nor localism is tenable, a line must be drawn among nonlocalized interests that accepts some, while rejecting others, as a basis for intervention. Presumably, the dividing line will shift over time. How should tribunals approach this inherently messy process? This kind of issue lends itself to case by case, common law development. But tribunals should also seek guidance from domestic legislation and international treaties.

The key to this approach, which I call the evolutionary approach, is collaboration between tribunals and lawmakers. Although this approach has not been worked out in any detail, it finds support in some reasoning in the Dutch

190. Indeed, charges of ecoimperialism have been made by less developed nations. See Vocke, supra note 112, at 149; Chang, supra note 68, at 2193-96. Of course, the concept of banishing power from intemational relations is childish, but if we purport to have an international legal system and judicial tribunals, they ought to at least make a pretense of principled dispute resolution.

191. See Sierra Club, 405 U.S. at 752.

192. Ironically, in some sense, each side implicitly recognizes the other set of values, but relegates them to a different sphere. Those individuals who favor free trade may be environmental localists, but they are economic globalists. Environmentalists adopt the opposite combination of views. Neither side seems to realize that they are accepting the same arguments in one sphere that they regard as illegitimate in the other. 
Grouse case and the separate opinions in Defenders. In the Dutch Grouse case, the Advocate General reconsidered his initial concern about the legitimacy of the Dutch extraterritorial interest in light of the directive's treatment of birds as a proper subject of transboundary concern. ${ }^{193}$ The ECJ judgment relied on a different rationale, but it did integrate the "constitutional" issue with its reading of the directive. In Defenders, while joining the Court's opinion on standing, Justice Kennedy saw room for legal evolution in collaboration with the legislature, even on this constitutional issue. ${ }^{194}$ Going a step further, Justice Stevens' concurrence in the judgment recognized a sufficient signal from the legislature in the Endangered Species Act's statement of policy. ${ }^{195}$ All of these opinions seem to contemplate, in one form or another, a dialogue between courts and lawmakers to delineate the geographic limits of environmental intervention.

Apart from the inevitable failure of any compromise to fully satisfy the interests in conflict, the evolutionary approach faces two criticisms. The first set of problems relate to the form of "legislative" participation in this process. Arguably, a tribunal should credit only formal action from an authoritative lawmaking body that deals specifically with the precise issue before the tribunal. A formality requirement would be helpful in some ways, but raises serious problems. In the international sphere, such formal actions may be sparse. Domestically, some question exists whether authoritative legislative action extending the scope of standing is actually within the legislative prerogative. In any event, evolution that relies solely on explicit formal legislation is likely to be halting at best.

Yet, if tribunals settle for less explicit signals from law makers, other objections arise. If a tribunal looks for guidance to a legislative action that does not precisely deal with the issue at hand, the tribunal is in some sense giving the legislation an expanded effect beyond its explicit scope. This broadening of legislative intent may be troubling to formalists. ${ }^{196}$ But judicial use of legislation as a source of analogy and guidance has a respectable formal pedigree even in American law, ${ }^{197}$ and is firmly embedded in the civil law. ${ }^{198}$ Caution is in order, however, since the tribunal risks upsetting a delicate compromise by giving one side more than it bargained for. Close attention to legislative intent is needed to ensure that explicit bargains are not upset.

The evolutionary approach's second set of problems relates to its potential plasticity. Localism and globalism seem analytically crisp, while the evolutionary approach requires judgment calls in changing legal settings. In short, the 55.

193. See Case C-169/89, Criminal Proceedings against Van den Burg, 1990 E.C.R. at 2143, 2154-

194. Defenders, 504 U.S. at 580.

195. Id. at 581-82.

196. A similar debate exists about the propriety of implying causes of action from federal statutes. See William N. Eskridge, Jr. \& Philip Frickey, Cases and Materials on Legislation: Statutes and the Creation of Public Policy 892-904 (2d ed. 1995).

197. See id. at $406-10$.

198. For examples of how the civil law has recognized this use of legislation, see INTERPRETING Statutes: A Comparative Study 81, 89, 200-01, 218-20, 318-20, 467 (D. Neil MacCormick \& Robert S. Summers eds., 1991) (citing various analysts). 
evolutionary approach arguably falls short of the formalist goals of predictability, stability, and immunity from manipulation. Although these are very real virtues, the sacrifice may be acceptable. In the first place the law of standing notoriously lacks these formalist virtues, ${ }^{199}$ so an evolutionary approach may do scant harm; a little extra mud will hardly be noticeable in the quagmire of standing law. As we saw in Part II, all free trade regimes-American, European, or international-already exhibit a great deal of flexibility in practice, so a strong need for certainty in the trade area may not exist. In short, we are not dealing here with the legal status of financial documents or land titles, where the legal system should deliver a very cleanly defined product.

At the very least, the flaws in the evolutionary approach do not seem inherently fatal. Only experience will show how serious these flaws are. The next sections analyzes two test cases.

\section{Applying the evolutionary approach to standing.}

The first test case is Defenders. ${ }^{200}$ Justice Scalia's majority opinion in this case rests on two premises about standing law: (a) that individual "injury in fact" is crucial to standing, and (b) that Congress cannot simply convey standing to anyone it wishes. Since this article addresses territoriality rather than standing law, those premises can be left unquestioned for present purposes. ${ }^{201}$ This makes it necessary to consider the scope of the geographic nexus: What kind of connection with a geographic area is necessary before an individual can claim "injury in fact" due to environmental harm in that area?

In attempting to sort out the possible types of injury, it is useful to recall the types of harm that an economist might recognize. As we saw earlier, some major categories include harm to use value, option value, and existence value. ${ }^{202}$ If injury is the key, it is unclear why in principle only use value should be included. As economists have found, however, there are significant methodological problems in measuring nonuse values. For the economist, the ultimate question in determining injury is whether the plaintiff would willingly pay to prevent the environmental harm at issue. The plaintiff's suit does not in and of itself prove such a willingness to pay, for many reasons exist to litigate besides protecting the specific geographic area at issue in the suit.

Apart from this measurement problem, we have also seen some normative difficulties with reliance on nonuse values. Those who lack any current physical connection with an area can be seen as engaging in a form of imperialism, overriding the preferences of others with a more immediate and concrete stake. Understandably, courts are generally reluctant to base standing on option value,

199. See generally Gene R. Nichol Jr., Abusing Standing: A Comment on Allen v. Wright, 133 U. Pa. L. Rev. 635 (1984) (criticizing what he considers the Burger Court's "erratic" standing doctrine); Mark V. Tushnet, The New Law of Standing: A Plea for Abandonment, 62 CORNELL L. REv. 663 (1977) (criticizing the law of standing as lacking "a rational conceptual framework").

200. Lujan v. Defenders of Wildlife, 504 U.S. 555 (1992).

201. These premises have, however, been cogently questioned. See Sunstein, supra note 58, at 186-92, 209-15.

202. See text accompanying notes $60-64$ supra. 
let alone existence value. On the other hand, as Defenders itself acknowledges, option value can be a concrete, recognizable value-for example, when the option is likely to be exercised in the near future. ${ }^{203}$ The problem arises over where to draw the line.

The evolutionary approach suggests that in drawing this line, we should attend to the views of other lawmaking bodies. The Endangered Species Act is clearly based on the view that the option and existence values of endangered species are not only real but dwarf use value. ${ }^{204}$ As Justice Stevens noted in his concurrence in Defenders, Congress endorsed the option and existence values on which the plaintiffs relied. ${ }^{205}$ Indeed, Congress viewed those values so highly that it created a nearly absolute rule of protection for endangered species, a rule that has been only mildly qualified since the original passage of the statute. ${ }^{206}$ This congressional judgment about the significance of option and existence values provides substantial validation for the plaintiffs' claims. Thus, the evolutionary approach strongly supports Justice Stevens' view of the case. ${ }^{207}$

What about the unpredictability of the evolutionary approach? In the context of standing to challenge government action, unpredictability offers some benefits. We may not want a government to be certain ex ante that its actions remain beyond judicial review. Here, a little unpredictability is not such a bad thing, since it means that the government is never sure that its illegal conduct will go uncorrected.

\section{Tuna-Dolphin revisited.}

Another test of the evolutionary approach comes from the tuna-dolphin cases. In assessing the validity of the trade measures used to protect the Pacific dolphin, the ultimate test is whether some legitimate regulatory interest sufficiently justifies the measures. As we saw in our survey of GATT law, the form of the regulation affects the location and weight of the burden of proof. ${ }^{208}$ For present purposes we can focus on a narrower question: whether the United States had any legitimate interest in the first place; otherwise, there is nothing to put onto the scales.

So far, GATT seems to have had a great deal of trouble in answering this question. The panel in Tuna-Dolphin I opted for strict territoriality. Besides being highly controversial, this answer makes it quite difficult to find the right technical formulation to reconcile GATT with the reality of modern international environmental law. ${ }^{209}$ The panel in Tuna-Dolphin II, in contrast, aban-

203. See Defenders, 504 U.S. at 564 n.2.; see also Sierra Club v. Marita, 46 F.3d 606, 611-14 (7th

Cir. 1995) (finding that Defenders does not change test for imminence).

204. See Tennessee Valley Authority v. Hill, 437 U.S. 153, 174-84 (1978) (summarizing the legislative history of the Endangered Species Act).

205. See 504 U.S. at 582-83 (Stevens, J., concurring in the judgment).

206. See Roger W. Findley \& Daniel A. Farber, Cases and Materials on Environmental LAw 772-78 (4th ed. 1995).

207. See text accompanying notes 53-54 supra.

208. See text accompanying notes $80-92$ supra.

209. For a thorough effort to work out such formulation, see Hudec, supra note 186, at 120-42. 
doned territoriality altogether as a limitation on government environmental objectives. In order to prevent a massive loophole in GATT, however, the panel was then forced to restrict artificially the choice of means to achieve these presumably legitimate goals. 210

Clearly, under the evolutionary approach, extraterritorial interests should not be ruled "out of order," but neither should they be automatically accepted. Rather, the tribunal should look to the evolving legal regime to see whether a particular government interest has received recognition. With respect to the MMPA, the answer is debatable. On the one hand are several factors favoring the legitimacy of the American claim. First of all, the claim relates to the global commons, where nonlocalist interests clearly are at their strongest.211 Moreover, as the panel points out, the dispute involved a migratory aquatic species, where GATT has previously seemed to recognize some non-local regulatory interests. ${ }^{212}$ Concern over marine mammals also has received international attention, most notably in connection with whales. On the other hand, the American case would certainly be much stronger if dolphins were an endangered or threatened species.

On balance, the most reasonable conclusion seems to be that the American interest is sufficiently well founded to avoid claims of mere officious intermeddling. Thus, the claims should be considered legitimate for GATT purposes. Further GATT analysis depends on an assessment of the strength of those claims relative to the trade restriction, under one test or another. In this assessment, the uncertain legitimacy of the American claims should count against them in the balance. ${ }^{213}$ Thus, while the American interest crosses the threshold of legitimacy, it may not be sufficiently strong to justify discriminatory or particularly burdensome trade effects.

The evolutionary approach does not provide a resolute, firm answer regarding the validity of the American trade measures. Although we have a natural desire for legal clarity, this lack of resoluteness actually may not represent a flaw. The controversy over the GATT rulings shows that both sides of this issue present strong values. Recognizing these competing values may complicate decision making, but the failure to recognize the competing values produces a Procrustean solution to a hard problem. Moreover, in the international arena, adjudication is always in the service of negotiation, and legal uncertainty may help prevent negotiating positions from hardening excessively.

\section{CONCLUSION}

As this article has shown, the Tuna-Dolphin and Defenders disputes epitomize a deeper tension between two conflicting world views. Localism requires

210. See text accompanying notes 119-121 supra.

211. See Stewart, supra note 108, at 1357-58; Christopher D. Stone, What to Do About Biodiversity: Property Rights, Public Goods, and the Earth's Biological Riches, 68 S. CAL. L. Rev. 577, 591-92 (1995).

212. Tuna-Dolphin II, supra note 113 , at para. 5.5 .

213. It is unclear whether any further justification for trade measures exists at present. See Charnovitz, supra note 122 , at 10,585 . 
a tight physical connection with an area as the basis for legitimate environmental concern. It resonates with traditional notions of territoriality. Globalism sees the world as so tightly interconnected that physical location becomes almost irrelevant. It also claims the support of emerging ecological consciousness. The evolutionary approach, which this article endorses, seeks to mediate between these two world views.

The evolutionary approach lacks the comforting clarity of localism and globalism. But those approaches achieve clarity only at the cost of ignoring inconvenient realities. Localism pretends that the environment, but not the economy, recognizes national borders. Globalism pretends that distance has been completely erased and that local communities have no claims to autonomy. In the end, the fuzziness of the evolutionary approach is preferable to such ill founded clarity. 